\title{
UTILIZATION OF DRIED PARSLEY LEAVES (PETROSELINUM CRISPUMM) AND THEIR ESSENTIAL OIL FOR EXTENDING SHELF LIFE OF BEEF BURGER
}

\author{
A.Z.M.Badee ${ }^{1 凶}$, Nadia A.E. Salama ${ }^{1}$ and Menna Allah K.I. ${ }^{2}$ \\ ${ }^{1}$ Food Science Department, Faculty of Agriculture, Cairo University, Giza, Egypt. \\ ${ }^{2}$ International Perfume Company, Giza, Egypt. \\ $\triangle$ d.badee1947@gmail.com \\ https://doi.org/10.34302/crpjfst/2020.12.4.5 \\ Article history: \\ Received: \\ 29 May 2020 \\ Accepted: \\ 1 November 2020 \\ Keywords: \\ Parsley leaves, \\ Essential oil, beef burger, \\ Antioxidant, \\ Physic-chemical \\ Characteristics, \\ Microbiological quality.

\section{ABSTRACT} \\ In an attempt to raise the quality and extend shelf life of beef burger, parsley \\ powder or its essential oil were added to the formula. Three different \\ formulas of beef burgers were prepared. The first one was formulated with \\ $0.5 \%$ dried parsley herb the second formulated with $600 \mathrm{ppm}$ of parsley \\ essential oil, and $3^{\text {rd }}$ was free from additions (control).The results showed \\ that the initial $\mathrm{pH}$ value of control beef burgers(C) and samples treaded with \\ parsley powder or oil ( $\mathrm{P}$ or $\mathrm{O}$ ) was the same( 5.8), but, after 8days of \\ storage at $4^{\circ} \mathrm{C}$, the $\mathrm{pH}$ value significantly increased in all samples the \\ highest increase was recorded for sample $(\mathrm{C})$, while sample $(\mathrm{O})$ had the \\ lowest increase. As for the, TBA values the data showed that addition of \\ parsley oil to burger formula $(\mathrm{O})$ significantly $(\mathrm{P} \leq 0.05)$ lowered the \\ TBA value than control sample $(C)$ at zero time of storage .The lowest \\ significant increase in TBA value of all treatments, after8 days of \\ storage at $4^{\circ} \mathrm{C}$, was recorded for $(\mathrm{O})$ sample. The results also indicated \\ that beef burger sample (O), at zero time ,had the highest significantly \\ cooking loss and the lowest cooking yield than other burger samples. \\ Simultaneously, beef burger sample (P) had the significant lower cooking \\ loss and the higher cooking yield than other beef burger samples. After cold \\ storage of all burger samples at $4^{\circ} \mathrm{C}$ for 8 days, cooking loss values of all \\ burger treatment were significantly increased. Control sample(C) had the \\ highest significant increase in cooking loss. At the same time, burger sample \\ (P) had the significantly higher cooking yield than other burger samples at \\ the end of storage period. Moreover, beef burgers containing parsley oil or \\ parsley powder have extended the lag phase period to 4 days while control \\ samples have lower lag phase period 2 days for total Bacterial Count (TBC) \\ and total Psychrotrophic bacterial Count. Same data indicated that parsley \\ oil has the highest inhibitory effect against TBC and psychrotrophs count at \\ zero time and till the end of cold storage. Meanwhile, parsley powder \\ recorded a lower inhibitory activity than parsley oils against TBC and \\ psychrotrophs count at zero time and till the end of storage. The results also \\ observed that the total of the three color spectral readings $L^{*}$, $a^{*}$ and $b^{*}$ \\ values of fresh beef burger are affected by formulation with parsley essential \\ oil or powder. Sensory evaluation showed that beef burger formulated \\ immediately with parsley oil was superior in all quality attributes compared \\ to samples formulated with or without powdered parsley. All recorded \\ sensory score characteristics of control samples, at the $8^{\text {th }}$ days, were \\ rejected. While samples formulated with parsley oil or powder were \\ acceptable till the $8^{\text {th }}$ day, with obvious superiority of beef burger formulated \\ with parsley oil.
}




\section{Introduction}

Elsharawy et al.(2018) reported that Enhancement of food safety is the major interest by increasing interest in natural preservatives, which has antioxidant, antimicrobial properties and more healthy specially in meat products which is highly susceptible to microbial growth, which can cause its spoilage and contributes to food borne diseases in human, resulting in serious health problems. Parsley (Petroselinum crispum) is a species of Petroselinum in the family Apiaceae, originated in Europe and the Mediterranean region (Italy, Greece, Egypt, Algeria, and Tunisia), and widely cultivated as a herb, a spice, and a vegetable.

Brkovic et al. (2006) reported that plants from family Apiaceae are commonly used as food, flavoring agents and for medical purposes and are also known as nutraceutical plants. Based on many studies, it seems that several species in this family are good sources for phytochemicals with potent antimicrobial and anti inflammatory properties.

Karimi et al. (2014) reported that parsley essential oil shown a variable degree of antimicrobial activity on different microorganisms. Therefore using parsley essential oil as antimicrobial additive in food may be useful and alternative medical therapy for microorganisms which may resist customary treatment. This will suggest a great help in facing appearance spread of bacteria.

Alsaiqali et al.(2016) stated that meat and meat products such as beef burger are subject to spoilage either by microbes or by fat oxidation. Accordingly, it is very important to protect them from spoilage by adding preservatives, especially natural preservatives to extend their shelf life and to improve their characteristics.

Alsaiqali et al. (2016) found that parsley oil had a great reduction effect on the numbers of TBC, S. enterica, E. coli, S. aureus and $P$. aeruginosa during the first 2

The objective of our study was to investigate the effect of formulate beef burger with parsley dry herb or its essential oil on its quality

\section{Materials and methods}

\subsection{Materials}

Ten $\mathrm{kg}$ of recently dried parsley herb (Petroselinum crispum) was purchased from Medicinal and Aromatic plants Research Department, Horticulture Research Institute, Horticultural Research Center, Giza, Egypt.

Fifty $\mathrm{ml}$. of parsley leaves essential oil were obtained as a gift from Greetco Co. Abo Elnomros, Giza, Egypt.

\subsection{Methods}

\subsubsection{Manufacturing of beef burgers:}

Three different formulas of beef burgers were prepared. The first one was formulated with $0.5 \%$ dried parsley herb, the second was formulated with600ppm of parsley essential oil, and $3^{\text {rd }}$ was free from additions (control). The beef burger formulas were prepared as described by Emrick et al. (2005) and compatible with EOS (2005) as presented in Table (1). All ingredients were mixed together in a blender to ensure uniform distribution of added ingredients.

Table 1. Formulation of beef burgers with dried parsley herb and its essential oil

\begin{tabular}{|l|c|c|c|}
\hline \multirow{2}{*}{ Ingredients } & \multicolumn{3}{|c|}{ Treatments \% } \\
\cline { 2 - 4 } & Control & Dried Parsley herb & Parsley herb oil \\
\hline Minced meat & 90 & 89.50 & 89.40 \\
\hline Salt & 1.5 & 1.5 & 1.5 \\
\hline Milk powder & 3 & 3 & 3 \\
\hline Spice mixture & 2 & 2 & 2 \\
\hline Fresh onion & 3.5 & 3.5 & 3.5 \\
\hline Parsley powder & - & 0.5 & - \\
\hline Parsley oil & - & - & $600 \mathrm{mg} / 1 \mathrm{~kg}$ meat \\
\hline
\end{tabular}


The burgers formulae were shaped manually using a patty maker (stainless steel model form) to obtain round discs of $10 \mathrm{~cm}$ in diameter and $0.5 \mathrm{~cm}$ thickness with average weight 50 gm. Burgers were packed in polyethylene bags and kept into laminated package and stored at $4^{\circ} \mathrm{C}$ for 8 days.

\subsubsection{Cooking of beef burgers}

The beef burgers were cooked for $4 \mathrm{~min}$ each side at $200^{\circ} \mathrm{C}$ as mentioned by Ali et al. (2011)

\subsubsection{Color of raw beef burgers}

Color measurement of different prepared beef burgers with dried and oils of parsley. color was measured by Chroma meter (Konica Minolta, model CR 410, Japan) calibrated with a white plate and light trap supplied by the manufacturer. Color was expressed using the CIE L*, a*, and b* color system (CIE, 1976). A total of three spectral readings were taken for each sample. Lightness $\left(\mathrm{L}^{*}\right)$ (dark $(0)$ to light $(100))$, the redness $\left(\mathrm{a}^{*}\right)$ values $((+)$ reddish to $(-$ ) greenish). The yellowness $\left(b^{*}\right)$ values $(+)$ yellowish to (-) bluish) were estimated. According to CIE (Commission International de l'E' Clairage) (1976). Official recommendations on uniform color spaces. Color difference equations and metric color terms, Suppl. No. 2. CIE Publication No. 15 Colourimetry, Paris.

Beef burger samples were analyzed in Cairo University Research Park (CURP), Faculty of Agriculture.

\subsection{Microbiological analysis}

The microbiological analysis of control sample and the two treated beef burger formulas (with dried parsley herb and its oil) includes the determination of total bacterial count and Psychrotrophic bacterial count.

\subsubsection{Sample preparation}

Ten grams of uncooked beef burger samples were mixed with $90 \mathrm{ml}$ of sterile saline solution $(8.5 \mathrm{gm} \mathrm{NaCl} / 1$ Ldistilled water) in a blender, under aseptic conditions, to give 1/10 dilution .Serial dilutions were prepared to be used for counting total bacterial count and psychrotrophic bacterial count, immediately after each storage period at Zero time (fresh), 2,4and 8days at $4^{\circ} \mathrm{C}$ according to American Public Health Association (APHA, 1992).

\subsubsection{Total Bacterial Count (TBC) and psychrotrophic bacterial count}

The total bacterial and psychrotrophic bacterial counts were determined using plate count agar medium according to the procedure described by (APHA,1992). The plates were incubated at $37^{\circ} \mathrm{C}$ for $48 \mathrm{~h}$, and $7^{\circ} \mathrm{C}$ for 10 days for total bacterial count and for psychrotrophic bacterial count, respectively. The results were expressed as colony forming units per gram (CFU/g).

\subsection{Chemical analysis of the beef burgers 2.4.1.Thiobarbituric acid (TBA)}

Extraction procedure:

Twenty grams of sample were homogenized with $100 \mathrm{mg}$ of butylated hydrxytoluene (BHT) and $100 \mathrm{ml}$ of $7.5 \%$ trichloroacetic acid (TCA) solution, mixed for one minute in solvents blender and filtered through a filter paper (Whatman No.1), then 5 $\mathrm{ml}$ of TBA reagent $(0.02 \mathrm{M}$ TBA, 0.2896 $\mathrm{g} / 100 \mathrm{ml}$ glacial acetic acid ) were added to 5 $\mathrm{ml}$ of filtrate in test tubes with screw caps. They were placed for $40 \mathrm{~min}$. in a boiling water bath. Absorbance was read at $538 \mathrm{~nm}$ after cooling in tap water, the original TCA extract was used as a blank,(Vyncke,1970). The TBA values were calculated according to(Zeb and Ullah , 2016).

$Y=1.4167 X+0.0785$

Where ' $\mathrm{x}$ ' is absorbance

\subsubsection{Measurement of $\mathrm{pH}$ value}

Beef burger samples (10 g) was homogenized with $50 \mathrm{~mL}$ deionized water for 1 min. The $\mathrm{pH}$ value was measured at room temperature using a digital $\mathrm{pH}$ meter3305, Jenway (Gahruie et al., 2017) 


\subsubsection{Sensory evaluation}

Cooked beef burger samples were sensory evaluated immediately after cooking. All cooked beef burger samples were cut to small slices and coded with random numbers as described by AMSA (1995). Sensory evaluation was performed by 12 panel from postgraduate students and staff of the faculty of Agriculture Cairo university. Evaluated five parameters as odor, color, taste, texture and over all acceptability using a 9-point hedonic scale, as follows (9 Excellent, 8 Very good, 7 Good, 6 Acceptable, 5 Poor). The mean values of the obtained results from sensory evaluation were statistically analyzed.

\subsection{Statistical analysis}

Data were statistically analyzed one way by analysis of variance, ANOVA, (Rao and Blane, 1985). Data were presented as means of 3 experiments \pm SD unless otherwise stated. All microbial data were transformed to logarithm before analysis.

\section{Results and discussion}

\subsection{Physico-chemical properties of beef burgers}

Data in Table (2) show the physicochemical properties of beef burgers as affected by addition of parsley oil $(600 \mathrm{ppm})$ or its powders $(0.5 \%)$. From these results observe the changes occurred in $\mathrm{pH}$ values of beef burgers during storage at $4^{\circ} \mathrm{C}$ for 8 days. The initial $\mathrm{pH}$ value of control beef burgers(C) and samples treaded with parsley powder or oil ( $\mathrm{P}$ and $\mathrm{O}$ ) was the same(5.8), but, after 8days of storage at $4^{\circ} \mathrm{C}$, the $\mathrm{pH}$ value significantly increased to 6.3 for sample(C), 6.2 and6.1 for samples(P),(O), respectively. Also, Elsharawy (2018) reported that the addition of oils or powder of parsley did not affected the $\mathrm{pH}$ values of meat products.

During cold storage at $4^{\circ} \mathrm{C}$ for 8 days, the $\mathrm{pH}$ values of burgers (control and with parsley oil or powder) were increased significantly with increasing storage time. The highest increase in
$\mathrm{pH}$ value (6.3) was recorded for control sample while, sample formulated with parsley oil had the lowest increased $\mathrm{pH}$ value (6.1). The Increase in $\mathrm{pH}$ value could be attributed to the formation of volatile basic nitrogen components as affected by biochemical changes under low temperature These results are in agreement with those obtained by Alsaiqali et al. (2016).

The increment of $\mathrm{pH}$ value of control burger samples might be due to the effect of microbial growth which may cause protein hydrolysis and release of nitrogenous compounds that increase the $\mathrm{pH}$ value of meat.

Also, the data in Table (2) indicate about the TBA values -the oxidative rancidity- of the samples. The limit of acceptance for TBA is proposed as $0.9 \mathrm{mg}$ as malondialdehyde/ $\mathrm{kg}$ raw minced beef, according to EOS (2005)". The data showed that the TBA values of (O) sample was significantly $(\mathrm{P} \leq 0.05)$ lower than control sample $(\mathrm{C})$ at zero time of storage. While the value of TBA determined in samples contained parsley herb was significantly insignificant from the control.

During 8 days of storage, the highest increase in TBA value was observed for control samples at the end of storage time, while samples contained parsley oil and parsley powder had lower TBA values. It is noticeable that greatest stability of burger samples was recorded for parsley oil sample(O) over parsley powder sample, where as they recorded to 0.36 or $0.38 \mathrm{mg}$ malondialdehyde $/ \mathrm{kg}$ sample, respectively, after 8days storage at $4^{\circ} \mathrm{C}$.IN addition, the increase in the value of TBA of the sample $(\mathrm{O})$ was significantly less than the increase in control(C). After the same time of storage the TBA value of control samples was twofold the beginning sample (it reached to $0.5 \mathrm{mg}$ malondialdehyde $/ \mathrm{kg}$ sample). Our results are agreements with those obtained by Abd El-Qader et al.(2004),, Kassem et al. (2011) and Alsaiqali et al.(2016). 
Badee et al. Carpathian Journal of Food Science and Technology, 2020, 12(4), 41-50

Table 2. Effect of addition of parsley oil (600ppm) or dried leaves powder $(0.5 \%)$ on $\mathrm{pH}$, TBA, Cooking loss and Cooking yield of beef burger during storage at $4^{\circ} \mathrm{C}$ for 8 days.

\begin{tabular}{|c|c|c|c|c|c|}
\hline & \multirow{2}{*}{ Treatments } & \multicolumn{4}{|c|}{ Storage time (day) } \\
\hline & & $\mathbf{0}$ & 2 & 4 & 8 \\
\hline \multirow{3}{*}{ pH } & Control (C) & $5.8^{\mathrm{Ac}} \pm 0.00$ & $6.0^{\mathrm{Ab}} \pm 0.07$ & $6.2^{\mathrm{Aa}} \pm 0.00$ & $6.3^{\mathrm{Aa}} \pm 0.07$ \\
\hline & Powder(P) & $5.8^{\mathrm{Ab}} \pm 0.07$ & $5.9^{\mathrm{Ab}} \pm 0.07$ & $6.1^{\mathrm{ABa}} \pm 0.07$ & $6.2^{\mathrm{Aa}} \pm 0.07$ \\
\hline & $\operatorname{Oil}(0)$ & $5.8^{\mathrm{Ab}} \pm 0.07$ & $5.9^{\mathrm{Ab}} \pm 0.07$ & $6.0^{\mathrm{Ba}} \pm 0.00$ & $6.1^{\mathrm{Aa}} \pm 0.00$ \\
\hline \multirow{3}{*}{$\begin{array}{l}\text { TBA } \\
\text { (mg malondialdehyde/kg) }\end{array}$} & Control (C) & $0.23^{\mathrm{Ac}_{ \pm}}+0.01$ & $0.28^{\mathrm{Ac}_{ \pm}} \pm 0.00$ & $0.38^{\mathrm{Ab}_{ \pm 0}}$ & $0.50^{\mathrm{Aa}_{ \pm}}+0.01$ \\
\hline & Powder(P) & $0.22^{\mathrm{ABd}} \pm 0.00$ & $0.25^{\mathrm{Bc}} \pm 0.00$ & $0.29^{\mathrm{ABb}} \pm 0.00$ & $0.38^{\mathrm{ABa}} \pm 0.00$ \\
\hline & $\operatorname{Oil}(0)$ & $0.20^{\mathrm{Bb}} \pm 0.00$ & $0.23^{\mathrm{Bb}} \pm .01$ & $0.27^{\mathrm{Bb}} \pm 0.00$ & $0.36^{\mathrm{Ba}} \pm 0.05$ \\
\hline \multirow{3}{*}{ Cooking loss (\%) } & Control (C) & $9.77^{\mathrm{Ac}} \pm 0.22$ & $10.52^{\mathrm{ABc}} \pm 0.41$ & $14.02^{\mathrm{Ab}_{ \pm}} 0.52$ & $15.39^{\mathrm{Aa}_{ \pm}} \pm 0.40$ \\
\hline & Powder(P) & $8.44^{\mathrm{Bb}} \pm 0.46$ & $9.00^{\mathrm{Bb}} \pm 0.62$ & $9.60^{\mathrm{Bb}} \pm 0.60$ & $12.13^{\mathrm{Ca}_{ \pm}}$ \\
\hline & $\operatorname{Oil}(0)$ & $10.48^{\mathrm{Ad}_{ \pm}} \pm 0.15$ & $11.53^{\mathrm{Ac}_{ \pm 0}} 0.64$ & $12.80^{\mathrm{Ab}_{ \pm}}+0.16$ & $13.82^{\mathrm{Ba}} \pm 0.04$ \\
\hline \multirow{3}{*}{ Cooking yield(\%) } & Control (C) & $90.24^{\mathrm{Ba}} \pm 0.22$ & $89.48^{\mathrm{ABa}} \pm 0.41$ & $85.99^{\mathrm{Bb}} \pm 0.52$ & $84.62^{\mathrm{Cc}} \pm 0.40$ \\
\hline & Powder(P) & $91.57^{\mathrm{Aa}} \pm 0.46$ & $91.01^{\mathrm{Ab}_{ \pm}}+0.62$ & $90.41^{\mathrm{Ac}} \pm 0.60$ & $87.87^{\mathrm{Ad}_{ \pm 0.30}}$ \\
\hline & $\operatorname{Oil}(0)$ & $89.53^{\mathrm{Ba}} \pm 0.15$ & $88.48^{\mathrm{Ba}} \pm 0.64$ & $87.20^{\mathrm{Ba}} \pm 0.16$ & $86.19^{\mathrm{Bb}} \pm 0.04$ \\
\hline
\end{tabular}

Any two means within the same column have different capital letters, and any two means within the same row have different small letters are significantly different at $\mathrm{P}<0.05$.

C: Control, P: Parsley Powder, O:Parsley Oil. SD, standard deviation of group means.

\subsection{Cooking loss}

The aim of cooking is to kill most of microorganism, inhibit toxic substance, augment digestibility and improve organoleptic properties of meat products. But cooking causes some loss in weighting (cooking loss) which affects the yield of cooked meat. Results in Table (2) showed the cooking loss and cooking yield of different studied treatments during storage at $4^{\circ} \mathrm{C}$. It could be observed that, beef burger sample treated with parsley oil(O), at zero time ,had the significantly higher cooking loss and the lower cooking yield than other beef burger samples, simultaneously, beef burger sample treated with parsley powder(P) had the significantly lower cooking loss and the higher cooking yield than other beef burger samples. After storage of all burger samples at $4^{\circ} \mathrm{C}$ for 8 days, cooking loss values of all burger treatment were significantly increased .Control sample $(\mathrm{C})$ had the highest significant increase in cooking loss .At the same time, burger sample $(\mathrm{P})$ had the significantly higher cooking yield than other beef burger samples at the end of storage period.

The significant decrease in cooking loss $\%$ and significant increase of cooking yield $\%$ in samples (P) than the (C)samples could be related to the Absorption capacity of parsley powder. On the other hand, cooking loss \% of samples (O) increased and cooking yield \% decreased than (C) samples, this could be attributed to the high loss of fat and oil during cooking as reported by (kim et al., 2016).

The higher cooking loss and lower cooking yield of(C) samples than the other samples could be attributed to the excessive fat separation and water release that occurred from breaking the emulsion during cooking (kim et al.,2016).

By increasing storage time at $4^{\circ} \mathrm{C}$, the cooking loss increased and cooking yield decreased of all studied samples formulas this may be occurring due to the decreasing in water holding capacity, moisture retention and fat retention of these treatments during storage. Similar trends in cooking loss were observed by Abd El-Qader (2004) and Ali (2008) who found that cooking loss of chicken and beef burger increased as the period of storage increased. Also, Abolgasem (2011) and Hamza (2011) mentioned that cooking loss of beef burger significantly increased by advancement of storage time. Moreover, Hussein (2015) 
reported that high cooking loss of fat burger might be attributed to the excessive fat separation during cooking.
Effect of addition of parsley powdered leaves or their essential oil to beef burger formula on total bacterial and Psychrotrophic counts during cold storage.

Table 3. Effect of addition of parsley powdered leaves or their essential oil to beef burger formula on total bacterial and psychrotrophic counts during cold storage $\left(4^{\circ} \mathrm{C}\right.$ for 8 days $)$.

\begin{tabular}{|l|c|c|c|c|c|}
\hline \multirow{2}{*}{ Treatments } & \multirow{4}{|c|}{ Storage time (day) } \\
\cline { 2 - 5 } & & $\mathbf{0}$ & $\mathbf{2}$ & $\mathbf{4}$ & $\mathbf{8}$ \\
\cline { 2 - 6 } & $\mathbf{C}$ & $3.8 \times 10^{4 \mathrm{Ad}}$ & $5.8 \times 10^{4 \mathrm{Ac}}$ & $3.5 \times 10^{5 \mathrm{Ab}}$ & $8.0 \times 10^{5 \mathrm{Aa}}$ \\
\cline { 2 - 6 } & $\mathbf{P}$ & $3.5 \times 10^{4 \mathrm{Bd}}$ & $4.8 \times 10^{4 \mathrm{Bc}}$ & $6.5 \times 10^{4 \mathrm{Bb}}$ & $5.0 \times 10^{5 \mathrm{Ba}}$ \\
\cline { 2 - 6 } & $\mathbf{O}$ & $3.2 \times 10^{4 \mathrm{Cd}}$ & $4.4 \times 10^{4 \mathrm{Cc}}$ & $5.4 \times 10^{4 \mathrm{Cb}}$ & $3.2 \times 10^{5 \mathrm{Ca}}$ \\
\hline $\begin{array}{l}\text { Psychrotrophs } \\
\text { (cfu/g) }\end{array}$ & $\mathbf{C}$ & $4.5 \times 10^{4 \mathrm{Ad}}$ & $8.0 \times 10^{4 \mathrm{Ac}}$ & $3.8 \times 10^{5 \mathrm{Ab}}$ & $7.4 \times 10^{5 \mathrm{Aa}}$ \\
\cline { 2 - 6 } & $\mathbf{P}$ & $4.0 \times 10^{4 \mathrm{Bd}}$ & $6.3 \times 10^{4 \mathrm{Bc}}$ & $9.5 \times 10^{4 \mathrm{Bb}}$ & $4.3 \times 10^{5 \mathrm{Ba}}$ \\
\cline { 2 - 6 } & $\mathbf{O}$ & $3.8 \times 10^{4 \mathrm{Cd}}$ & $5.0 \times 10^{4 \mathrm{Cc}}$ & $8.0 \times 10^{4 \mathrm{Cb}}$ & $3.7 \times 10^{5 \mathrm{Ca}}$ \\
\hline
\end{tabular}

Any two means within the same column have different capital letters and any two means within the same row have different small letters are significantly different at $\mathrm{P}<0.05$.

C: Control, P: Parsley Powder, O: Parsley Oil

Table (3) Shows the effect of formulate beef burger with parsley powdered leaves $(0.5 \%)$ or their essential oil $(600$ ppmon total bacterial count and total psychrotrophic bacterial count during storage at $4^{\circ} \mathrm{C}$ for 8 days. Beef burgers containing parsley oil or parsley powder have extended the lag phase period to 4 days while control samples have lower lag phase period 2 days for total Bacterial Count (TBC) and total Psychrotrophic bacterial Count. Same data indicated that parsley oil has the highest inhibitory effect against TBC and Psychrotrophs count at zero time and till the end of cold storage. Meanwhile, parsley powder recorded lower inhibitory activity than parsley oils against TBC and psychrotrophs count at zero time and till the end of storage. Similar results were recorded by Alsaiqali et al.,(2016) who also noticed the effect of essential oils on burger after few days of cold storage.

The reported reduction of TBC rates might referred to the presence of some antibacterial compounds in parsley oils or powder as, (flavonoids) which affect most microorganisms and the bacteriostatic compounds as phenols. Similar results reported by Wong and Kitls (2006); Ashour et al.(2014), Farah et al.(2015) and Alsaiqali et al.(2016) who observed that the extract of dill and parsley had significant reduction of TBC and dill was more effective than parsley extract. Moreover Alsaiqlali et al.(2016) concluded that parsley extract had a strong antimicrobial effect against TBC, E.coli ,S.aureus during the first storage period however this effect reduced by time. We recommended to using parsley oils and powder as a safe and natural antimicrobial meat additive to prolong shelf life of meat burger.

Total bacterial counts and Psychrotrophic bacterial count in control samples was significantly higher $(\mathrm{P} \leq 0.5)$ than the samples containing parsley oil(600ppm) and samples containing parsley powder $(0.5 \%)$ at zero time of storage at $4^{\circ} \mathrm{C}$. These results have the same trend with the results obtained by Elsharawy (2018). 


\subsection{Color measurement}

Color measurements can be used as an indirect way to estimate undesirable change in food products, since it is a simple and faster method than chemical analysis Gahruie et al. (2017)

Table 4. Changes in beef burger color due to formulation with parsley oil or powder

\begin{tabular}{|l|c|c|c|}
\hline Samples & $\mathbf{L}^{*}$ & $\mathbf{a}^{*}$ & $\mathbf{b}^{*}$ \\
\hline Control & $44.0^{\mathrm{B}} \pm 0.26$ & $11.8^{\mathrm{A}} \pm 0.23$ & $4.2^{\mathrm{B}} \pm 0.06$ \\
\hline Oil & $45.1^{\mathrm{A}} \pm 0.25$ & $11.2^{\mathrm{B}} \pm 0.14$ & $6.6^{\mathrm{A}} \pm 0.41$ \\
\hline Powder & $44.5^{\mathrm{B}} \pm 0.35$ & $8.6^{\mathrm{C}} \pm 0.16$ & $7.2^{\mathrm{A}} \pm 0.49$ \\
\hline
\end{tabular}

Any two means have different capital letters at the same column are significantly different at $\mathrm{P}<0.05$. $\pm=$ SD standard deviation of group mean.

Results in Table (4) showed that the lightness ( $\mathrm{L}^{*}$ value) of the burger samples ranged from 44.0 for control to 45.1 for samples with parsley oil and 44.5 for samples treated with parsley powder. The control samples and which treated with parsley powder had significantly lower L value when compared with sample treated with parsley oil. Also redness and yellowness ( $\mathrm{a}^{*}$ and $\mathrm{b}^{*}$ value) ranged from 11.8 to 8.6 and 4.2 to 7.2 for control and samples treated with parsley powder, respectively. The burger samples which treaded with parsley powder had lower redness value than other treatments. On the other hand $b^{*}$ value (yellowness)was higher for samples treaded with parsley powder and parsley oil when compared with control. Results showed that the yellowness ( $b *$ value) of parsley powder was significantly higher than the control sample. These results are in agreement with Riel et al.(2017) who found that, the Internal contents of parsley extract as a nitrite source in mortadella sausages led to the rise in $b^{*}$ value of the sausage.
In general, it could be concluded that $\mathrm{L}^{*}, \mathrm{a}^{*}$ and $b^{*}$ values of fresh beef burger are affected by formulation with parsley oil $(600 \mathrm{ppm})$ or powder $(0.5 \%)$.

\subsection{Sensory evaluation}

Results reported in Table (5) observed the means values of sensory characteristics of beef burger formulated with parsley powder or its essential oil (odor, taste, texture, color and overall acceptability) immediately after formulation and during cold storage at $4{ }^{\circ} \mathrm{C}$ for 8 days. The results showed that beef burger formulated with parsley oil was superior in all quality attributes compared to samples formulated with or without powdered parsley. Parsley oil samples got the highest significant scores of odor, color, taste and overall acceptability, but parsley powder samples got the highest, insignificant, scores of texture when compared with samples formulated with parsley oil as shown in Table (5). These data declared that formulation of beef burger with parsley oil , and to a lower extent parsley powder, improve most of its quality attributes.

Table 5.Effect of parsley oil and parsley powder on sensory evaluation of beef burger during storage at $4^{\circ} \mathrm{C}$ for 8 days.

\begin{tabular}{|c|c|c|c|c|c|c|}
\hline Treatments & $\begin{array}{c}\text { Storage } \\
\text { (days) }\end{array}$ & Odor & Color & Taste & Texture & $\begin{array}{l}\text { Overall } \\
\text { acceptability }\end{array}$ \\
\hline \multirow{4}{*}{ Control(C) } & $\mathbf{0}$ & $8.0^{\text {bcd }} \pm 0.60$ & $8.5^{b c} \pm 0.52$ & $8.2^{\mathrm{cde}} \pm 0.58$ & $8.1^{b} \pm 0.29$ & $8.1^{b c} \pm 0.67$ \\
\hline & 2 & $7.9^{\mathrm{bcd}} \pm 0.58$ & $8.3^{c} \pm 0.49$ & $8.0^{\text {cde }} \pm 0.29$ & $8.0^{\mathrm{b}} \pm 0.43$ & $8.0^{\mathrm{bc}} \pm 0.43$ \\
\hline & 4 & $6.8^{\mathrm{e}} \pm 0.62$ & $7.7^{\mathrm{d}} \pm 0.49$ & $6.5^{\mathrm{f}} \pm 0.52$ & $7.0^{\mathrm{c}} \pm 0.74$ & $7.0^{\mathrm{d}} \pm 0.60$ \\
\hline & 8 & $5.0^{\mathrm{f}} \pm 0.74$ & $5.5^{f} \pm 0.52$ & $4.3^{\mathrm{h}} \pm 0.78$ & $6.6^{c} \pm 0.51$ & $4.8^{\mathrm{f}} \pm 0.72$ \\
\hline
\end{tabular}


Badee et al. Carpathian Journal of Food Science and Technology, 2020, 12(4), 41-50

\begin{tabular}{|c|c|c|c|c|c|c|}
\hline \multirow{4}{*}{ Powder(P) } & $\mathbf{0}$ & $8.3^{\mathrm{b}} \pm 0.65$ & $7.5^{\mathrm{d}} \pm 0.90$ & $8.6^{\mathrm{bc}} \pm 0.67$ & $9.2^{\mathrm{a}} \pm 0.83$ & $8.5^{b} \pm 0.67$ \\
\hline & 2 & $8.1^{b c} \pm 0.67$ & $7.4^{\mathrm{d}} \pm 0.79$ & $8.1^{\text {bcd }} \pm 0.52$ & $9.0^{\mathrm{a}} \pm 0.79$ & $8.4^{\mathrm{b}} \pm 0.67$ \\
\hline & 4 & $7.7^{\mathrm{cd}} \pm 0.49$ & $7.4^{\mathrm{d}} \pm 0.79$ & $7.7^{e} \pm 0.65$ & $8.1^{b} \pm 0.79$ & $7.8^{\mathrm{c}} \pm 0.39$ \\
\hline & 8 & $6.8^{\mathrm{e}} \pm 0.45$ & $6.0^{\mathrm{ef}} \pm 0.60$ & $5.7^{g} \pm 0.78$ & $7.0^{c} \pm 0.43$ & $5.9^{e} \pm 0.67$ \\
\hline \multirow{4}{*}{$\operatorname{Oil}(0)$} & $\mathbf{0}$ & $9.3^{\mathrm{a}} \pm 0.62$ & $9.2^{\mathrm{a}} \pm 0.58$ & $9.2^{\mathrm{a}} \pm 0.72$ & $9.1^{\mathrm{a}} \pm 0.67$ & $9.3^{\mathrm{a}} \pm 0.65$ \\
\hline & 2 & $9.2^{\mathrm{a}} \pm 0.58$ & $9.0^{\mathrm{ab}} \pm 0.43$ & $9.0^{\mathrm{ab}} \pm 0.43$ & $9.1^{\mathrm{a}} \pm 0.60$ & $9.1^{\mathrm{a}} \pm 0.51$ \\
\hline & 4 & $8.3^{\mathrm{b}} \pm 0.49$ & $8.4^{\mathrm{c}} \pm 0.51$ & $8.0^{\mathrm{de}} \pm 0.43$ & $8.0^{\mathrm{b}} \pm 0.60$ & $8.0^{\mathrm{bc}} \pm 0.60$ \\
\hline & 8 & $7.5^{\mathrm{d}} \pm 0.5 .2$ & $6.5^{\mathrm{e}} \pm 0.52$ & $6.0^{\mathrm{fg}} \pm 0.74$ & $6.6^{c} \pm 0.51$ & $6.1^{\mathrm{e}} \pm 0.67$ \\
\hline
\end{tabular}

Any two means have different superscript letters within the same column are significantly different at $\mathrm{p}<0.05$.

$\pm=\mathrm{SD}$, standard deviation of group means.

$\mathrm{C}=$ control, $\mathrm{P}=$ powder $0.5 \%$ and $\mathrm{O}=$ oil $600 \mathrm{ppm}$.

9=Excellent $8=$ Very good $7=$ Good $6=$ Acceptable 5= Poor

The sensory characteristics of all burger samples showed continuous decrease along storage period and the lowest quality attributes were reported on the $8^{\text {th }}$ day of storage for control sample.

All recorded sensory score characteristics of control samples, at the $8^{\text {th }}$ days, were rejected. While samples formulated with parsley oil or powder were acceptable till the $8^{\text {th }}$ day, with obvious superiority of beef burger formulated with parsley oil.

It is worth to mention that significant improvements of odor, taste and texture of burger samples which treated with parsley oil or powder could be attributed to the aromatic effect of parsley oil or powder as reported by Mishra and Dubey (1994), Lawless (1995). Therefore, much attention in recent years has been focused on the use of extracts from herbs and spices to improve sensory characteristics, retard lipid oxidation and extended the shelf life of meat products (Arorakour,1999, Gulluce et al.,2003 and Lagouri and Nisteropoulou, 2009).

\section{Conclusions}

From the obtained results it could be concluded that addition of parsley oils or powder to beef burger formula at concentration of $600 \mathrm{mg} / \mathrm{kg}$ or $0.5 \%$ respectively, not only to minimize lipid oxidation but also to improve sensory characteristics and enhanced the wholesomeness of the product during refrigeration storage due to lower TBA value and microbial load. We recommended to use parsley oil or powder as a safe and natural antimicrobial meat additive to prolong shelf life of beef burger and, above all, the improvement of most sensory properties.

\section{References}

Abd El-Qader, M. F. (2004). Quality Improvement of Chicken Frozen Burger Formulated with Some Spices or their Volatile Oils, M.Sc. Thesis, Food Sci. Dept., Fac. Agric., Cairo Univ., Egypt, 301.

Abolgasem, F.S. (2011). Effect of Oat Flakes as a Fat Replacer on Chemical, Physical and Sensory Properties of Low-Fat Beef Burgers. M.Sc. Thesis, Food Sci. Dept., Fac. Agric., Cairo Univ., Egypt, 122.

Ali, M. A. (2008). Effect of Processing and Cooking Methods on Chemical, Biological and Microbiological Properties of Low-Fat Meat Products. Ph.D. Thesis, Food Sci. Dept., Fac. Agric., Cairo Univ., Egypt, 109.

Ali, R. F.; El-Anany, A.M. and Gaafar, A.M. (2011). Effect of potato flakes as fat replacer on the quality attributes of low-fat beef patties. adv. J. Food Sci. Technol., 3(3):173-180.

Alsaiqali, M., El-Shibiny, A.A., Adel, M., Abdel-Samie, M.A.S. and Ghoneim, S. (2016). Use of Some Essential Oils as Antimicrobial Agents to Control Pathogenic Bacteria in Beef Burger. World 
Journal of Dairy \& Food Sciences 11 (1), 109-120.

AMSA. (1995). American Meat Science Association. Research guidelines for cookery, sensory evaluation and instrumental tenderness of fresh meat. National Livestock and Meat Board. Chicago, IL.

A. P. H. A., (1992). In standard Methods for the Examination of dairy products. $16^{\text {th }}$ (Ed) by Marshall, R.T. American Public Health Association. Washington, D.C., USA.

Arora, D.S. and Kaur, J. (1999). Antimicrobial activity of spices. Int. J. Antimicrob. Ag., 12, 257-262.

Ashour, M.M.S., R.K. Moawad and G.F. Bareh, (2014). Quality enhancement and shelf-life extension of raw beef patties lactate/thyme essential oil during refrigerated storage. J. Appl. Sci. Res. Formulated With, 9(13): 6699-6709.

Brkovic, L., Ljiljana, C. and Slavica, S. (2006). Antibacterial activity of some plants from Family Apiaceae in relation to selected phytopathogenic bacteria, Kragujev. J. Sci., 28: $65 \mathrm{e} 72$.

CIE (Commission International de l'E' Clairage) (1976). Official recommendations on uniform color spaces. Color difference equations and metric color terms, Suppl. No. 2. CIE Publication No. 15 Colourimetry. Paris.

Elsharawy, N. T. (2018). Control of some food -borne pathogens on some meat products using dill (Disambiguation) and Parsley (Petroselinum crispum) essential oils International. Journal of Current Research Vol., 10, Issue, 07,72055-72064.

Emrick, M.E., Penfield, M., Bacon, C.D. and Brekke, C.J. (2005). Heat intensity and warmed-over flavor in precooked chicken patties formulated at 3 fat levels and 3 pepper levels. Journal of Food Science, 70(9), S600-S604.

EOS (2005). Egyptian Standards (2005). Frozen beef burgers. Egyptian Organization for Standardization and Quality Control,
Ministry of Industry and Technological Development, Arab Republic of Egypt (E.S. No.1688).

Farah, H., Elbadrawy, E. and Al-Atoom, A.A. (2015). Evaluation of antioxidant and antimicrobial activities of ethanolic extracts of Parsley (Petroselinum crispum) and Dill plants grown in Saudi Arabia. J. Adv. Res., 3(4): 1244-1255.

Gahruie, H.H., Hosseini, S.M.H., Taghavifard, M.H., Eskandari,M.H., Golmakani,M.T and Shad, E. (2017).Lipid Oxidation, Color Changes, and Microbiological Quality of Frozen Beef Burgers Incorporated with Shirazi. Journal of Food Quality, 1-9.

Gulluce, M., Sokmen, M. Daferera, D., Agar, G., Ozkan, H., Kartal, N., Polissiou, M., Sokmen, A. and Sahin, F. (2003). In vitro antibacterial, antifungal, and antioxidant activities of the essential oil and methanol extracts of herbal parts and callus cultures of Saturejahortensis L. J. Agric. Food Chem., 51, 3958-3965.

Hamza, R. A. (2011). Effect of Some Spices and Type of Frying oil on Quality Attributes of Semi-Fried Chicken Fingers During Frozen Storage. M.Sc. Thesis, Food Sci. Dept., Fac. Agric., Cairo Univ., Egypt, 204.

Hussein, S. A. (2015). Effect of Wheat bran and barley as fat Replacers on quality characteristics beef sausage during frozen storage. Middle East J. of Appl. Sci., 5(2), 618-629.

Karimi, F., Rezaei, M., Shariatifar, N., Sayadi, M., Mohammad pourfard, I., Malekabad, E. and Jafar, H. (2014). Running Head: Antimicrobial activity of Parsley Antimicrobial Activity of Essential oil of Parsley (Petroselinum crispum) Against Food Pathogenic Bacteria. World Applied Sciences Journal, 31(6): 1147-1150.

Kassem, G.M., Atta-Alla, O.A. and Ali, F.H.M. (2011). Improving the quality of beef burger by adding thyme essential oil and jojoba oil. Arch. Zootec, 60 (231), 787-795.

Kim, H.-W, Hwang, K.E, Song, D.H, Kim, Y.J., Ham, Y.K., Jeong, T.J., Chio, Y.S and 
Kim, C.J. (2016). Germinated barley as afunctional ingredient in chicken sausages: Effect on physicochemical and technological properties at different levels. J. Food Sci. Tech., 53(1): 872-879.

Lagouri, V. and Nisteropoulou, E. (2009). Antioxidant properties of $O$. onites, $T$. vulgaris and $O$. basilicum species grown in Greece and their total phenol and rosmarinic acid content. J. Food Lipids, 16: 484-498.

Lawless, J. (1995). The illustrated encyclopedia of essential oils. Element books Ltd. Shaftesbury.UK.

Mishra, A.K. and Dubey, N.K. (1994). Evaluation of some essential oils for their toxicity against fungi causing deterioration of stored food commodities. Appl. Environ. Microb., 60, 1101-1105.

Rao, V.N.M. and Blane, k. (1985). PC-STAT, Statistical Programs for microcomputers: Food Sci. and Tecno1. Dep., Georgia Univ., Version 1A. Athens, GA, USA.

Riel, G., Boulaaba, A., Popp, J., and Klein, G. (2017). Effects of parsley extract powder as an alternative for the direct addition of sodium nitrite in the production of mortadella-type sausages - Impact on microbiological, physicochemical and sensory aspects. Meat Science, 131, 166175.

Vyncke, W., (1970). Direct determination of the thiobarbituric acid value in trichloracetic acid extracts of fish as a measure of oxidative rancidity. Fette. Seifen. Anstrichmittel,72(12): 1084-1087.

Wong, P. Y.Y. and Kitts, D. D. (2006). Studies on the dual antioxidant and antibacterial properties of parsley (Petroselinum crispum) and cilantro (Coriandrum sativum) extracts. Food Chemistry, 97: 505-515.

Zeb, A., and Ullah, F. (2016). A Simple Spectrophotometric Method forthe Determination of Thiobarbituric Acid Reactive Substances in Fried Fast Foods. Journal of Analytical Methods in Chemistry, 1-5. 